\title{
EFEKTIFITAS LOGOTERAPI MEDICAL MINISTRY TERHADAP MOTIVASI PASIEN HEMODIALISA DENGAN HARGA DIRI RENDAH DI RUMAH SAKIT DI KOTA PADANG
}

\author{
Rizka Ausrianti' ${ }^{1,}$ Rifka Putri Andayani \\ Prodi S I Keperawatan ${ }^{1}$ Prodi D III Keperawatan ${ }^{2}$ \\ STIKes MERCUBAKTIJAYA Padang \\ rizka.ausrianti@gmail.com ${ }^{1}$,rifkaputriandayani@gmail.com ${ }^{2}$
}

\begin{abstract}
Hemodialysis is a procedure that must be performed for patients with chronic kidney disease. This will result in changes in the patient's life including psychosocial changes in low self-esteem, which can result in decreased motivation, they are more dominant in viewing negative aspects of themselves and are less motivated in seeking the meaning of their life or in achieving life goals. This study aims to determine the effect of medical ministry logotherapy on motivation in hemodialysis patients with low self-esteem in the city of Padang. The design used in this research is "Quasy Experimental PrePost Test With Control Group". The research was conducted at the Reksodiwiryo Hospital, Padang. The sampling technique was consecutive sampling with a sample size of 86 people, where 43 people were each group. Samples were selected with inclusion criteria, namely willingness to become respondents, not experiencing decreased awareness, communication and never getting individual medical ministry logotherapy and being able to read and write. The results showed that medical ministry logotherapy was very effective on the motivation of hemodialysis patients with low selfesteem in the intervention group with $p$ value 0,000, while in the control group medical ministry logotherapy was not effective against motivation with $p$ value 0.171. It can be concluded that medical ministry logotherapy is very effective in motivating hemodialysis patients with low self-esteem and there is a difference between the intervention group and the control group. It is hoped that hemodialysis patients with low self-esteem can be given specialist medical ministry logotherapy therapy.
\end{abstract}

Keywords $\quad$ : Hemodialysis,Logotherapy,Lowself-Asteem,Motivation.

\begin{abstract}
ABSTRAK
Hemodialisa merupakan prosedur yang harus dilakukan untuk pasien dengan penyakit ginjal kronik. Hal ini akan mengakibatkan terjadinya perubahan dalam kehidupan pasien diantaranya perubahan psikososial harga diri rendah, yang dapat mengakibatkan penurunan motivasi, mereka lebih dominan memandang aspek negatif dirinya dan kurang termotivasi dalam mencari makna kehidupannya ataupun dalam pencapaian tujuan hidup. Penelitian ini bertujuan untuk mengetahui pengaruh logoterapi medical ministry terhadap motivasi pada pasien hemodialisa dengan harga diri rendah di kota padang. Desain yang digunakan dalam penelitian ini adalah "Quasy Experimental Pre-Post Test With Control Group". Penelitian dilakukan di Rumah Sakit Reksodiwiryo Padang. Teknik pengambilan sampel yaitu consecutive sampling dengan jumlah sampel 86 orang, dimana 43 orang masing - masing kelompok. Sampel dipilih dengan kriteria inklusi yaitu bersedia menjadi responden, tidak mengalami penurunan kesadaran, komunikasi dan belum pernah mendapatkan logoterapi individu medical ministry serta bisa baca dan menulis. Hasil penelitian menunjukan logoterapi medical ministry sangat efektif terhadap motivasi pasien hemodialisa dengan harga diri rendah pada kelompok intervensi dengan $p$ value 0,000 , sedangkan pada kelompok kontrol logoterapi medical ministry tidak efektif terhadap motivasi dengan $p$ value 0,171 . Dapat disimpulkan bahwa logoterapi medical ministry sangat efektif terhadap motivasi pasien hemodialisa dengan harga diri rendah dan terdapat perbedaan antara kelompok intervensi dengan kelompok kontrol. Diharapkan pasien hemodialisis dengan harga diri rendah dapat diberikan terapi spesialis logoterapi medical ministry.
\end{abstract}

Kata kunci $\quad$ : Hemodialisa,Harga Diri Rendah,Logoterapi,Motivasi. 


\section{PENDAHULUAN}

Prevalensi Penyakit Ginjal Kronik (PGK) saat ini meningkat pesat di seluruh dunia dan di akui sebagai masalah kesehatan global (Indonesian Renal Registry (IRR) ,2014 . Kasus penyakit ginjal kronik terdapat 120.668 kasus dimana terjadi peningkatan $1.1 \%$ dari tahun 2013. Di Indonesia angka kejadian penyakit ginjal kronik berdasarkan data dari PERNEFRI (2017) penyakit ginjal kronik menempati urutan ke sepuluh dari sepuluh penyakit terbanyak, dimana prevalensi gagal ginjal kronis 0,2 \% dari penduduk Indonesia( PERNEFRI (2017) . Penyakit ginjal kronik ini jika gejala berkembang menjadi stadium 5 akan berefek pada kematian, kecuali dilakukan terapi pengganti ginjal seperti hemodialisis. Hemodialisis biasanya dilakukan seumur hidup ( Jameson \& Loscalzo, 2013; Black, J.M \& Hawks, 2014). Sehingga dapat menimbulkan berbagai permasalahan. Permasalahan yang timbul akibat ketergantungan pada alat dialisis atau harus melakukan hemodialisa seumur hidupnya, antara lain terjadinya perubahan dalam kehidupan pasien, seperti perubahan biologis, psikologi, sosial, spiritual. Salah satunya perubahan psikologi seperti harga diri rendah sehingga menyebabkan penurunan motivasi (KEMENKES RI, 2017).

Pasien hemodialisa dengan harga diri, mereka lebih dominan memandang aspek negatif dirinya dan kurang termotivasi dalam mencari makna kehidupannya ataupun dalam pencapaian tujuan hidup. Oleh karena itu untuk meningkatkan harga diri pada pasien hemodialisa, maka Intervensi keperawatan yang dapat dilakukan seorang perawat dalam mengatasi diagnosa keperawatan dimulai dengan intervensi keperawatan generalis sampai dengan spesialis yang ditujukan untuk individu, keluarga dan kelompok (Stuart, 2016).

Logoterapi adalah salah satu terapi spesialis dalam upaya memusatkan penemuan makna hidup dimana mengarahkan klien untuk berusaha mengembangkan sikap (attitude) yan tepat dan positif dan merealisasikan nilai-nilai bersikap (attitude values) sebagai salah satu sumber makna hidup (Bastaman, 2007).

Logoterapi bertujuan untuk mengembangkan diri untuk meraih kualitas hidup yang lebih bermakna dan mengubah sikap terhadap penderitaan sebagai alat untuk menemukan tujuan hidup (Bastaman, 2007; Wong, 2016).Logoterapi individu merupakan salah satu terapi individu yaitu logoterapi medical ministry dapat bermanfaat untuk mendapatkan berupa nilai-nilai bersikap seperti menerima dengan penuh ketabahan, kesabaran, keberanian menghadapi bentuk penderitaan yang tidak mungkin terelakkan serta memberikan semangat hidup menjadi bermakna. Oleh karena itu melalui logoterapi medical ministry diharapkan pasien yang menjalani hemodialisa dengan harga diri rendah dapat mengambil sikap yang positif terhadap permasalahan yang dialami selama menjalani hemodialisa, sehingga dapat meraih kualitas hidup yang lebih bermakna.

\section{METODE}

Desain yang digunakan dalam penelitian ini adalah "Quasy Experimental Pre-Post Test With Control Group". Penelitian dilakukan di Rumah Sakit Reksodiwiryo Padang. Teknik pengambilan sampel yaitu consecutive sampling dengan jumlah sampel 86 orang, dimana 43 orang masing - masing kelompok. Sampel dipilih dengan kriteria inklusi yaitu bersedia menjadi responden, tidak mengalami penurunan kesadaran, komunikasi dan belum pernah mendapatkan logoterapi individu medical ministry serta bisa baca dan menulis. Penelitian ini telah dilakukan pada tanggal 23 Maret - 04 April 2020, yang di mulai kegiatan penyusunan proposal dan pengumpulan data, penilaian motivasi sebelum diberikan logoterapi pada kelompok intervensi an kelompok kontrol, 
dilanjutkan pelaksanaan logoterapi medical ministry lakukan secara individu pada kelompok intervensi, dan terakhir dilakukan kembali penilaian motivasi sesudah diberikan logoterapi medical ministry pada kelompok kontrol dan intervensi.

Alat ukur yang digunakan untuk penilaian motivasi adalah Treatment Motivation Quetionnairre (TMQ). Kuesioner ini terdiri dari domain motivasi intrinsik dan ekstrinsik. Pertanyaan terdiri dari 26 item dengan jenis favorabel pada nomor 1-11, 14-15, 17-20, 22, 23, 25, 26 dan yang unfavorabel pada nomor 12, 13, 16, 21, 24. Masing-masing pertanyaan mempunyai pilihan jawaban dengan skor 1 sampai 5. Item favorabel yaitu di mulai dengan 1 yaitu sangat tidak setuju, 2 yaitu kurang setuju, 3 yaitu netral, 4 yaitu agak setuju, 5 yaitu sangat setuju. Sedangkan untuk item unfavorabel yaitu di mulai dengan 1 yaitu sangat setuju, 2 yaitu agak setuju, 3 yaitu netral, 4 yaitu kurang setuju dan 5 yaitu sangat tidak setuju.

Sedangkan untuk pelaksanaan logoterapi medical ministry melalui 4 sesi pelaksanaan dalam waktu pelaksanaan 2 minggu terdiri dari sesi 1 mengidentifikasi penyebab masalah. Padatahap tahap ini, terapis memperkenalkan diri, menanyakan perasaan klien, menjelaskan tujuan serta manfaat dari pelaksanaan logoterapi. Terapis mengidentifikasi masalah yang muncul akibat penahanan. Klien yang terlibat didalam logoterapi kelompok diberikan kesempatan untuk mengungkapkan pendapatnya masingmasing. Sesi 2 yaitu mengidentifikasi reaksi dan respon klien terhadap masalah. Pada tahap ini Klien diminta untuk mengungkapkan reaksi atau respon ketidakberdayaan yang dialami oleh klien. Adapun respon tersebut meliputi respon emosional, perilaku, partisipasi dalam kegiatan sehari-hari dan tanggung jawab klien dalam keterlibatan perawatan penyakit. Terapis menanyakan kepada klien cara yang dilakukan untuk mengatasi masalah tersebut, bagaimana hasilnya serta mengidentifikasi masalah yang belum teratasi. Sesi 3 yaitu tekhnik medical ministri. Pada tahap ini Membantu merealisasikan nilai-nilai bersikap sebagai salah satu sumber dalam menemukan makna hidupnya. Sedangkan pada sesi 4 yaitu evaluasi, pada tahap ini mengevaluasi hasil pelaksanaan logoterapi melalui teknik medical ministry, menemukan makna hidup yang klien dapatkan dan mampu menerima perpisahan. Terapis mendiskusikan bersama klien mengenai masalah yang sudah dan belum teratasi. Pada akhir sesi ini, terapis mendiskusikan rencana tindak lanjut dari masalah yang belum terselesaikan.

Secara umum prinsip etik yang menjadi dasar penelitian ini adalah Right to self determination ( memegang prinsip), anonimity ( kerahasiaan, confidentially, benefience dan justice. Serta Analisa data yang digunakan pada penelitian ini yaitu menggunakan uji $\mathrm{T}$ dependent dengan derajat kepercayaan $95 \%$.

\section{HASIL}

Motivasi sebelum dan sesudah pemberian logoterapi individu medical ministry pada kelompok intervensi dan kelompok kontrol

Motivasi pada pasien yang menjalani hemodialisa pada kelompok intervensi dan kontrol, sebelum dan sesudah pemberian intervensi Logoterapi Medical Ministry dapat di lihat pada tabel 1 berikut :

Tabel 1. Analisis Motivasi Sebelum Dan Sesudah Pemberian Logoterapi Individu Medical Ministry Pada Kelompok Intervensi Dan Kelompok Kontrol Di Rumah Sakit Di Kota Padang

\begin{tabular}{|c|c|c|c|}
\hline \multirow{2}{*}{ Variabel } & \multicolumn{2}{|c|}{ Motivasi } & \multirow{2}{*}{ PValue } \\
\hline & Mean & $95 \% \mathrm{CI}$ & \\
\hline \multicolumn{4}{|l|}{ Intervensi } \\
\hline Sebelum & 68,95 & $\begin{array}{l}33,269- \\
37,708\end{array}$ & 0,000 \\
\hline Sesudah & 104,44 & & \\
\hline \multicolumn{4}{|l|}{ Kontrol } \\
\hline Sebelum & 71,21 & $\begin{array}{l}0,136- \\
0740\end{array}$ & 0,171 \\
\hline Sesudah & 70,51 & & \\
\hline
\end{tabular}


Berdasarkan tabel 1 di atas terlihat rerata motivasi sebelum perlakuan pada kelompok intervensi adalah adalah 68,95 dan setelah perlakukan rerata motivasi menjadi 104,44. Sedangkan pada kelompok kontrol nilai rerata motivasi sebelum perlakuan adalah 71,21 dan setelah perlakuan 70,51 .

\section{Perbedaan motivasi pada kelompok intervensi dan kelompok kontrol setelah pemberian intervensi Logoterapi Individu Medical Ministry Pada Pasien Hemodialisa dengan Harga Diri Rendah.}

Hasil analisis perbedaan motivasi sebelum dan sesudah pemberian Logoterapi Medical Ministry pada kelompok intervensi dan kelompok kontrol di uji dengan Independent test sampel, dapat di lihat pada tabel 2 berikut.

\begin{tabular}{|c|c|c|c|c|}
\hline Tabel & \multicolumn{4}{|c|}{$\begin{array}{l}\text { 2. Perbedaan Motivasi Pada } \\
\text { kelompok Intervensi Dan } \\
\text { Kontrol setelah Pemberian } \\
\text { Logoterapi Individu Medical } \\
\text { Ministry Di Rumah Sakit Di Kota } \\
\text { Padang Tahun 2020 }\end{array}$} \\
\hline \multirow{2}{*}{$\begin{array}{c}\text { Variab } \\
\text { el }\end{array}$} & & Motivasi & & \\
\hline & Mean & SD & $\begin{array}{c}95 \% \\
\text { CI }\end{array}$ & $P$ \\
\hline $\begin{array}{c}\text { Interv } \\
\text { ensi }\end{array}$ & 35,49 & 7,21 & $\begin{array}{c}32,9- \\
37,3\end{array}$ & $\begin{array}{c}0,0 \\
00\end{array}$ \\
\hline $\begin{array}{c}\text { Kontr } \\
\text { ol }\end{array}$ & 0,35 & 1,38 & $\begin{array}{c}32,8- \\
37,3\end{array}$ & \\
\hline
\end{tabular}

Berdasarkan tabel 2 di atas, terlihat perbedaan rerata motivasi setelah diberikan Logoterapi Medical Ministry pada kelompok intervensi dan kelompok kontrol. Rerata motivasi setelah diberikan logoterapi Medical Ministry pada kelompok intervensi adalah 35,49 dan rerata motivasi pada kelompok kontrol adalah 0,35. Hasil analisis menunjukkan terdapat perbedaan signifikan pada motivasi setelah perlakuan antara kelompok intervensi dengan kelompok kontrol ( $\mathrm{p}=0,000 ; \alpha=$ $0,05)$.

\section{PEMBAHASAN}

Hasil penelitian terhadap motivasi pasien hemodialisa dengan harga diri rendah di Rumah Sakit di Kota Padang, sebelum dilakukan logoterapi medical ministry menunjukan motivasi rendah dengan rata- rata 68,95 , setelah dilakukan logoterapi medical ministry mengalami peningkatan menjadi 104,44, selisih peningkatan sebesar 35,49. Dapat disimpulkan motivasi mengalami peningkatan secara signifikan setelah dilakukan logoterapi medical ministry dengan hasil $p$ value 0,000 .

Hal tersebut didukung oleh beberapa perubahan pernyataan pasien hemodialisa dengan harga diri rendah, sebelum logoterapi medical ministry alasan melakukan perawatan tentang keinginan perubahan dalam hidup pasien hemodialisa dengan harga diri rendah sebanyak 69,8 \% ragu-ragu, setelah dilakukan logoterapi medical ministry mengalami perubahan menjadi 11,6\%, perasaaan tidak nyaman jika tidak melakukan hemodialisa sebelum logoterapi medical ministry 51,2 \% ragu-ragu, setelah dilakukan logoterapi medical ministry menjadi $7 \%$, dan perasaan menyesal karena penyakit yang diderita sehingga harus menjalani hemodialisa sebelum logoterapi medical ministry 90,7 \% ragu-ragu, setelah logoterapi medical ministry menjadi 0 $\%$.

Sementara itu, alasan untuk tetap melakukan perawatan tentang masalah yang akan didapat jika tidak hemodialisa, sebelum logoterapi medical ministry $93 \%$ ragu-ragu setelah logoterapi medical ministry menjadi 2,3\%. Kegagalan dalam pengobatan yang sedang dijalani sebelum logoterapi medical ministry $93 \%$ ragu-ragu, setelah logoterapi medical ministry menjadi 18,6 \%. Sedangkan untuk beberapa pernyataan tentang hemodialisa, keyakinan akan 
hemodialisa bermanfaat terhadap penyakit ginjal kronik sebelum logoterapi medical ministry $100 \%$ raguragu, setelah logoterapi medical ministry menjadi $30,2 \%$, penerimaan pasien hemodialisa terhadap kenyataan bahwa dia memerlukan bantuan dan dukungan dari orang lain sebelum logoterapi medical ministry 95,3 \% ragu-ragu, setelah logoterapi medical ministry menjadi $14 \%$.

Intervensi penelitian yang diberikan untuk responden pada kelompok intervensi adalah logoterapi individu medical ministry. Logoterapi adalah suatu jenis psikoterapi yang mengacu pada spiritual,existensial, dan terapi yang mengkonsentrasikan dalam pencarian makna hidup (Wong. P, 2002). Menurut Bastaman (2007) logoterapi adalah terapi yang menggambarkan corak psikologis/psikiatri yang mengakui adanya dimensi kerohanian pada manusia. Pada logoterapi Marshall (2010) menjelaskan bahwa terdapat beberapa azas logoterapi, yaitu hidup itu tetap memiliki makna atau arti dalam setiap situasi, bahkan dalam penderitaan dan kepedihan sekalipun. Manusia memiliki kebebasan yang hampir tak terbatas untuk menemukan sendiri makna hidupnya, dan setiap manusia memiliki kemampuan untuk mengambil sikap terhadap penderitaan, dan peristiwa tragis yang tidak bisa terelakkan lagi yang menimpa diri sendiri dan lingkungan sekitar.

Tekhnik logoterapi terdapat beberapa metode antara lain : paradoxical intention, dereflection, dan medical ministry. Pada penelitian ini peneliti menggunakan tekhnik logoterapi individu medical ministry, yaitu membantu individu mencari makna hidup dengan mengembangkan sikap yang tepat, seperti menerima dengan penuh ketabahan, kesabaran, keberanian menghadapi bentuk penderitaan yang tidak mungkin terelakkan, seperti sakit yang tidak dapat disembuhkan lagi.

Beberapa penelitian yang terkait dengan keberhasilan logoterapi medical ministry diantaranya penelitian yang dilakukan oleh Riethof et al, (2019) terjadi peningkatan harga diri pada lansia di panti werdha Malang setelah diberikan terapi logoterapi kelompok. Penelitian Orth et al, (2014)menemukan penurunan respon ketidakberdayaan yang signifikan pada kelompok yang mendapatkan terapi generalis dan logoterapi individu dibanding kelompok yang hanya mendapatkan terapi generalis. Hasil penelitian lain juga menunjukan peningkatan 20-40 makna hidup pada individu dengan disabilitas fisik karena kecelakaaan dan seluruh subjek melaporkan perubahan positif, berupa rasa semangat menjalani kehidupannya, menilai diri berharga, dan keinginan mengembangkan diri untuk menjadi produktif (Lestari, Mar, \& Kartasasmita, 2017). Penelitian Handayani, Hamid \& Mustikasari (2017) menunjukan terdapat perubahan depresi pada pasien hemodialisa, setelah mendapatkan terapi logoterapi medical ministry, yang terlihat dengan perubahan prilaku negatif kearah positif. Klien mempunyai komitment yang tinggi untuk melakukan terapi hemodialisa dan taat terhadap program pengobatan dan perawatan.

Peneliti menganalisis bahwa keberhasilan logoterapi medical ministry, terhadap peningkatan harga diri pasien hemodialisa dengan harga diri rendah. Berdampak terhadap perubahan motivasi pasien hemodialisa dengan harga diri rendah. Dikarenakan peneliti telah melakukan kegiatan sesuai dengan langkah/tahapan dalam teorinya. Hal ini dapat di lihat pada saat pelaksanaan sesi ke tiga logoterapi medical ministry yaitu tekhnik medical ministry. Responden mengungkapkan perasaan yang belum teratasi seperti perasaan marah, sedih, menyesal, 
menyalahkan diri sendiri, kehilangan harapan, malu dan pesimis, pada sesi ini dilakukan tekhnik medical ministry tekhnik satu dan dua. Tekhnik satu yaitu dengan mengingat kembali penderitaan waktu lalu yang pernah dialami, bagaimana perasaan dan cara mengatasinya waktu itu, kemudian perasaan sekarang atas pengalaman tersebut serta mengambil hikmahnya akan hal tersebut.

Tekhnik ke dua yaitu dengan menghubungi kenalan yang pernah mengalami penderitaan yang sama dan menanyakan hikmah yang diperolehnya serta membandingkan dengan keadaan sekarang. Hal yang diperoleh responden tersebut adalah lebih mendekatkan diri kepada Allah SWT, menganggap ini adalah cobaan hidup dan harus mampu menjalani hidup untuk kedepannya. Selain itu, responden mengungkapkan lebih bersyukur karena masih diberi kesempatan untuk mendekatkan diri kepada Allah SWT, serta lebih bersyukur karena ada orang lain yang lebih berat kondisinya yang mampu untuk melewati masalah. Sedangkan sesi ke empat responden mengungkapkan makna hidup yang didapatkan setelah menggunakan tekhnik medical ministry yaitu lebih mendekatkan diri kepada Allah SWT dan lebih banyak bersyukur.

Pengaruh Logoterapi Medical Ministry Terhadap Motivasi pada kelompok kontrol Pasien Hemodialisa Dengan Harga Diri Rendah. Berdasarkan hasil penelitian, motivasi tidak mengalami peningkatan secara signifikan setelah dilakukan logoterapi medical ministry dengan hasil $p$ value 0,171 .

Berdasarkan analisis peneliti, terjadi peningkatan terhadap motivasi pada pasien dengan harga diri rendah tetapi tidak signifikan. Hal ini disebabkan karena perubahan harga diri pada pasien hemodialisa dengan harga diri rendah, tidak hanya didapatkan dengan tindakan logoterapi medical ministry saja.
Terdapatnya dukungan optimal yang didapatkan klien dari keluarga dan lingkungan sehingga pasien mampu untuk meningkatkan harga diri. Namun hal tersebut belum maksimal untuk meningkatkan harga diri. Oleh karena itu perlu memberikan suatu tindakan keperawatan khususnya untuk meningkatkan harga diri pasien yang sedang menjalani hemodialisa. Pada akhirnya meningkatkan motivasi, seperti logoterapi medical ministry

Hasil analisis menunjukan terdapat perbedaan motivasi pada kelompok intervensi dan kelompok kontrol setelah diberikan diberikan logoterapi medical ministry. Hasil tersebut didukung dengan hasil analisis data dengan nilai $p$ value 0,000. Berdasarkan hasil dokumentasi pelaksanaan logoterapi medical ministry sesi satu dan dua, didapatkan bahwa $75 \%$ responden mengemukakan masalahnya terkait dengan program menjalankan hemodialisa. Mereka ingin melepaskan diri dari program pengobatan tersebut. Kehidupan mereka bergantung terhadap mesin dialisis, sehingga membuat hidup mereka menjadi bosan, tidak berdaya, dan tidak bermakna. Keadaan yang dialami responden tersebut disebut dengan existensial vacum.

Menurut Frankl, (2014) seseorang yang kehilangan makna dalam hidupnya akan berada pada existensial vacum dan selanjutnya existensial frustration. existensial frustration adalah respon emosional terhadap proses kehilangan makna dan tujuan dalam hidup. Penelitian Romadhoni \& Setyawati (2013) menyatakan bahwa terdapat hubungan antara penyesuaian diri dengan kebermaknaan hidup pada penderita ginjal kronik di RSUD Banyumas. Penderita yang memiliki penyesuaian diri tinggi maka memiliki makna hidup yang tinggi, begitu juga sebaliknya apabila penyesuaian diri rendah maka makna hidup juga rendah. 
Selain itu, hal yang dirasakan oleh pasien hemodialisa dengan harga diri rendah yang menjalani hemodialisa adalah merasa kehilangan motivasi dalam menjalankan hemodialisa. Menurut Orth et al, (2014) pasien yang menjalani hemodialisa yang mengalami harga diri rendah tidak mempunyai motivasi untuk bekerja dan untuk beraktifitas. Terdapatnya permasalahan tersebut tentu akan menghambat pasien dalam menjalani terapi. Hal tersebut dapat disimpulkan bahwa motivasi juga dapat menjadi faktor yang sangat berpengaruh dalam menjalankan program pengobatan.

Menurut Bastaman (2007) prinsip logoterapi medical ministry adalah proses pemahaman dan pengenalan diri yang sejujurnya, terkait dengan sumber potensi makna yang di miliki ( self knowledge), asosiasi dengan pengalaman positif terdahulu yang memberikan makna serta integrasi dengan pengaruh makna ke orang lain. Selanjutnya adalah motivasi atau keinginan responden untuk mengambil keputusan dalam memilih cara atau kemampuan yang dapat membantunya dalam menemukan makna (Wong. P, 2016). Adapun proses yang disebutkan diatas bahwa motivasi juga menjadi faktor yang berpengaruh dan menentukan keyakinan serta menentukan tentang program pengobatan yang diterima. Pada penelitian ini yang dilakukan pada kelompok intervensi, didapatkan bahwa responden menunjukan perubahan motivasi dan makna hidup yang signifikan dibandingkan kelompok kontrol. Hal tersebut dikarenakan anggota kelompok memiliki motivasi dan keinginan kuat untuk bermakna dalam situasi apapun yang merupakan sikap secara keseluruhan responden sejak awal mulai logoterapi medical ministry.

Keadaan tersebut berbeda dengan kelompok kontrol, dimana perubahan motivasi yang diperoleh tidak terlalu signifikan mengalami perubahan. Pada kelompok kontrol tidak ada dilakukan intervensi, oleh karena itu perlu dilakukan tindakan keperawatan untuk responden hemodialisa dengan harga diri rendah, karena hal ini juga dapat mempengaruhi dalam program pengobatan yang harus di jalani.

\section{KESIMPULAN}

Dapat disimpulkan bahwa terdapat pengaruh logoterapi medical ministry pada pasien hemodialisa dengan harga diri rendah di Rumah Sakit di Kota Padang pada kelompok intervensi, sedangkan pada kelompok kontrol tidak terdapat pengaruh logoterapi medical ministry pada pasien hemodialisa dengan harga diri rendah di Rumah Sakit di Kota Padang. Terdapat perbedaan signifikan antara motivasi antara kelompok intervensi dan kelompok kontrol sesudah diberikan logoterapi medical ministry pada pasien hemodialisa dengan harga diri rendah di kota Padang. Dan terdapat beberapa hal yang dapat disarankan demi keperluan pengembangan dari hasil penelitian seperti aplikasi dalam keperawatan keperawatan logoterapi medical ministry dapat dijadikan panduan perawat spesialis jiwa dalam melaksanakan Logoterapi medical ministry di Rumah Sakit umum dengan masalah psikososial khususnya dengan harga diri rendah. Secara keilmuan perlunya pemberian sosialisasi kepada perawat terkait logoterapi medical ministry dalam upaya meningkatkan harga diri pasien yang menjalani hemodialisa. Sedangkan untuk metodologi selanjutnya perlu dilakukan penelitian lanjutan dengan menggunakan desain penelitian yang berbeda, seperti randomized controled trial (RCT), sehingga dapat mengevaluasi intervensi yang digunakan untuk menunjukan bahwa intervensi benar-benar layak digunakan. 


\section{DAFTAR PUSTAKA}

Bastaman.H.D. (2007). Logoterapi : psikologis. (K. Wijaya, Ed.) (Edisi II). Jakarta: Mitra Aksara.

Black, J.M \& Hawks, H. (2014). Keperawatan medikal bedah (Edisi 8 $\mathrm{Bu})$.

Frankl, Viktor E. (Viktor Emil) (2014-0624). The will to meaning : foundations and applications of logotherapy (Expanded ed.). New York, New York. $\underline{\text { ISBN }} 9781101664025$. OCLC 934802526.

Indonesian, P., Registry, R., Renal, I., Indonesia, P. N., Kesehatan, D., Kesehatan, D., ... Irr, L. (2014). 7 th Report Of Indonesian Renal Registry 20147 th Report Of Indonesian Renal Registry 2014.

J.L Jameson \& Loscalzo. (2013). Harrison: Nefrologi dan gangguan asam basa,(Harrison's nephrologi and acid - base disordes. Jakarta: EGC.

Lestari, A., Mar, S., \& Kartasasmita, S. (2017). PERANAN MEDICAL MINISTRY DALAM MENINGKATKAN MAKNA HIDUP ( MEANING IN LIFE ) PADA INDIVIDU DENGAN DISABILITAS FISIK KARENA KECELAKAAN ( STUDI DI PANTI SOSIAL X ), 1(2), 310-316.

Marshall. (2010). Pris of Meaning: Guide to the Fundamental Princples Logoterapi.

Mustikasari (2017). Penurunan tingkat depresi klien gagal ginjal kronik yang menjalani hemodialisa dengan logoterapi medical ministry dan terapi komitmen penerimaan, 2, 78-88

Orth U.; Robbins R.W. (2014). "The development of self-esteem". Current Directions in Psychological Science.23 (5): 381-387. doi: $10.1177 / 0963721414547414$.

PERNEFRI. (2017), Report of indonesia renal registry. $\left(4^{\text {th }}\right) 1-39$
Romadhoni, M., \& Setyawati, R. (2013.). Hubungan antara penyesuaian diri dengan kebermaknaan hidup pada penderita penyakit ginjal kronik di rsud banyumas, $0,11-17$.

Stuart W Gail. (2016). Prinsip dan praktik keperawatan kesehatan jiwa stuart. ( keliat B. Anna, Ed.) (indonesia). singapore: Elsevier.

Wong, P. T. P. (2016). Integrative meaning therapy: From logotherapy to existential positive interventions. In P. Russo-Netzer, S. E. Schulenberg, \& A. Batthyany (Eds.). To thrive, to cope, to understand: Meaning in positive and existential psychotherapy (pp. 0-0). New York, NY: Springer. 